\title{
Empirical Study on Influence of Educational Environment on Satisfaction of Career Planning Teachers
} _Empirical Evidences for Career Planning Education of Universities in Hubei Province

\author{
QI Xiaolin ${ }^{1 a}$, LI Dekui $^{2 b}$
}

\author{
${ }^{1}$ Wuhan Technology and Business University, Wuhan 430000, China; \\ ${ }^{2}$ Wuhan Technology and Business University, Wuhan 430000, China; \\ a10120217@qq.com, b20413503@qq.com
}

Keywords: College students' career planning education, Education environments, Teachers' satisfaction.

\begin{abstract}
In recent years, in the face of increasing employment pressure of college students, college students' career planning education problem is a hot spot of society in the area of our country college students' education. Based on colleges in Hubei province as the research sample, this paper uses the theory of satisfaction to empirical about the impact of education environment on the teachers' satisfaction, such as funds investment, teacher training, education management etc., from the perspective of career planning education environment. Results show that these environmental factors have a positive effect to the career planning teachers' satisfaction. According to the research conclusion, it put forward the countermeasures and suggestions. This paper has the certain enlightenment significance to give relevant government departments and colleges advice to improve career planning education environment, improve the satisfaction degree of the teachers of career planning, promote the development of career planning education.
\end{abstract}

\section{Introduction}

The $21^{\text {st }}$ century has brought not only rapid economic development and progress in science and technology but also the increasing pressure on college students due to the swift replacement by emerging occupations and fiercely competitive labor market in China. Under this background, a large number of universities throughout the country have offered the course of career planning and employment guidance for college students as required and instructed by the competent governmental departments for education. Hence, this will greatly guide college students to understand themselves and environment correctly, plan their career reasonably, and solve employment problems practically.

To college students, the education for career planning and employment guidance is not only related to practical selection, but also an issue to be further studied theoretically and answered definitely. In the western countries with developed market economy, the study on this issue started in the early $20^{\text {th }}$ century. Now, a complete theoretical system has been developed as it has been studied for more than 100 years, including vocational guidance theory and trait-factor theory (Parsons, 1909), vocational interest theory (John Holland, 1985), career anchor theory (Schein, 1975), career development theory and five stage theory (Super, 1953; Greenhaus, 1987), nine stage theory (Schein, 1978), three stage theory (Ginzberg, 1951), career decision theory and cognitive information processing theory (Peterson, 1991), etc. Compared with the studies in western countries, the study on the education for career planning and employment guidance to college students started very late in China. At present, Chinese scholars are introducing and absorbing the relevant foreign theories and realizing the importance of this issue. However, China has different national conditions from the western countries, so these theories should not be simply copied from the western countries, but only borrowed from them.

Based on the above analysis, this paper takes the universities and colleges in Hubei Province as the research sample, and applies the satisfaction theory in the empirical analysis to find out the 
influences of environmental factors in career planning educational environment on the satisfaction of career planning teachers, including fund income, teacher training and teaching management, etc.

\section{Theoretical Analysis and Research Hypotheses}

Financial Investment of Universities in Career Education. It is commonly believed that universities invest more in career education, so career planning teachers are more satisfied with teaching and research environment and students have higher satisfaction with the effect of career education. In foreign countries, governments invest considerably in career counseling. In 1971-1977, the U.S. Government appropriated USD 658 million in the "career education" experiment and "career education five-year plan", and the Employment Guidance Center of University of Southern California received the annual fund of USD 420,000, while the Graduation Guidance Center of University of California (Los Angeles) had the annual fund of USD 1.5 million (Chen Peng, 2010). However, the financial investment of domestic governments in career education is obviously insufficient, while the governments at all levels and universities lack the attention to career education for college students, and do not establish the special institution or assign full-time personnel for regular management and implementation. Governments do not make any special investment in career education, so there is not any financial guarantee for such education (Huang Xinjian, Zhu Lixin, Zhao Ming, 2011). No matter whether it is a public university or private university, teachers always attribute the problems of poor career planning education in the university to its insufficient attention, including crowded classroom, single form of tutoring, insufficient student participation, and lack of career practical activities, etc. (Tan Min, 2007; Li Limin, Zhou Yong, 2010). Also, teachers blame universities for problems in teacher training, including lack of career counseling capability, insufficient professional quality, and lack of qualified teachers (Yang Minmin, Xu Enxiu, 2006; Ren Xueli, 2008). Based on the above analysis, the following hypothesis is given in the empirical study:

H1: The higher investment of university in career education, the higher satisfaction of career planning teachers.

Financial Investment of Universities in Teacher Training. The overseas studies on career planning teachers reveal that the teachers for career counseling should be diverse. Every career counselor of the U.S. Stanford University specializes in a professional field. In Australia, six basic capabilities are imposed for career guidance staff, i.e. professional knowledge and practical capability, vocational education and guidance capability, vocational tutoring capability, course and program design capability, organizational management and negotiation capability and information resource management capability. In the United States, the director of career guidance center in any university is normally required to have the master or doctoral degree, and any other full-time staff should also obtain the master degree in tutoring and counseling, etc. The professional teachers for vocational guidance in Province of British Columbia, Canada must be subject to the approval of the Ministry of Education, and should have not only academic and teaching capabilities, but also practical work experience. Moreover, counselors are required to have doctoral degree in education, psychology, counseling or corresponding humanities and social sciences, and also have related work experience. Tutors or management personnel should also have the master degree in humanities and social sciences (Chen Peng, 2010).

At present, career planning teachers in a university are basically teachers or staff from different majors and departments of the university, so they have complicated academic backgrounds, professional backgrounds, vocational qualifications and posts. For the needs of work or personal interest, some teachers choose to take part in career planning education. However, unprofessional "part-time" teachers do not know well about or master the professional knowledge and teaching methods of career education (Huang Xinjian, Zhu Lixin, Zhao Ming, 2011). Now, China has no unified codes or guidance for qualification and certification of these teachers, but there are the qualifications borrowed from the United States, i.e. GCDF and BCC, and the domestic qualifications including occupational coach technician, entrepreneur facilitator etc. The 
professionalization of teachers with complicated backgrounds will inevitably require universities to invest more in teacher training.

Based on the above analysis, the following hypothesis is given in the empirical study:

H2: The more specialized trainings universities provide for career planning teachers, the higher satisfaction of career planning teachers.

Attention of Universities to Teaching Reform in Career Education. It is commonly believed that the satisfaction of teachers can be improved if universities encourage and urge teachers to reform and explore the teaching contents and methods, while their satisfaction can enhance the teaching level and quality correspondingly. The studies on career education often focus on the reform of teaching methods and contents, and teachers put forward all kinds of specific methods and measures for career planning education, with an aim to improve own teaching level (Lu Naigui, Zhong Yani, 2006). Similarly, career planning teachers also have expectations for the teaching management of universities, and believe that the improvement of teaching system will positively affect their teaching level and quality (Liu Zhaoping, 2007).

Based on the above analysis, the following hypothesis is given in the empirical study:

H3: The more supports universities give to teachers in the reform of teaching contents and methods, the higher satisfaction of career planning teachers.

Perfectness of Career Educational System in Universities. Career education should be not only a course, but also a system in universities. In a university, teaching affairs department and administration for career planning education should bear the responsibility for establishing the educational system. The career planning system for college students should be established from the approaches of course, counseling, evaluation, activity and team (Li Bingkuan, Liu Qihui, 2005). Career counseling must be guaranteed at institutional, structural, talent, technical, organizational and theoretical levels (Xu Ming, Chen Xiaoping, 2011). When a university establishes a perfect career planning education system in such aspects as design, operation and management, the team of career planning teachers will be further improved.

Based on the above analysis, the following hypothesis is given in the empirical study:

H4: The more prefect career educational system universities have, the higher satisfaction of career planning teachers.

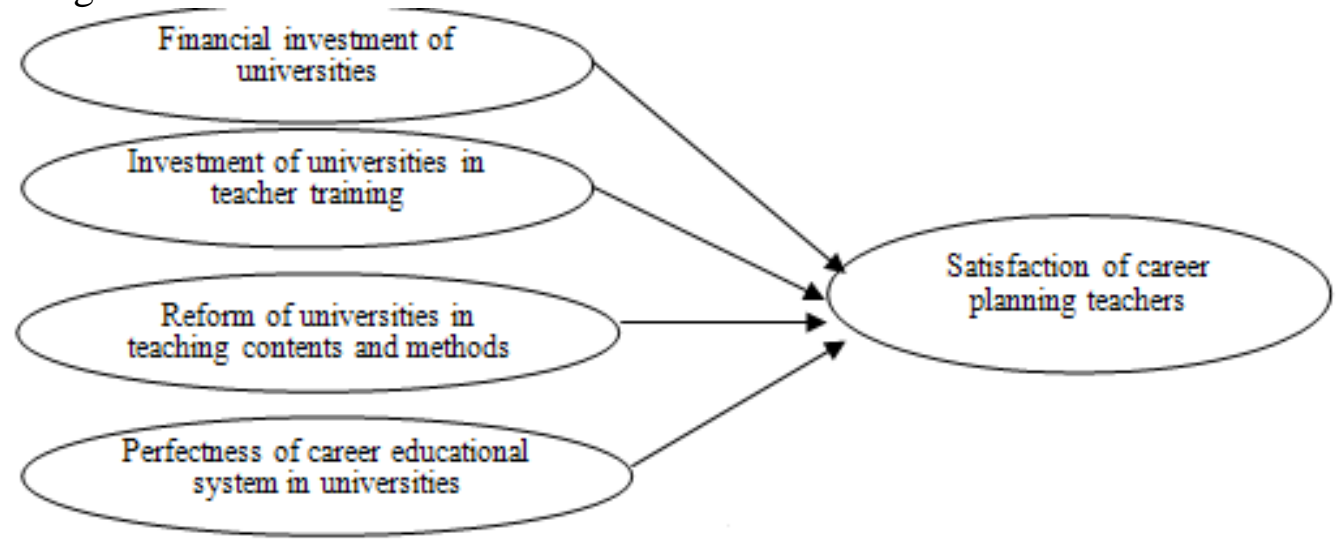

Fig. 1 Influence of educational environment on satisfaction of career planning teachers Note: The solid lines in this figure represent positive influence.

\section{Research Design}

Design of Variables and Questionnaire. This paper intends to study the influencing factors of career education development in universities, consults with the existing research achievements for the measurement of variables, and adjusts the problems reflected in the interview and survey and the opinions of experts. The measurement indicators are shown in Table 1 and Table 2. The questions about dependent variables are designed with Likert 5 point scale to give 1 to 5 points in the comments from "Very Satisfying” to "Very Unsatisfying”.

(1) Explained variables. The survey scale is independently designed, and used to measure the 
satisfaction of career planning teachers with their answers to 5 questions.

(2) Explanatory variables. They are measured with questions designed in 4 aspects of educational environment, including financial investment of universities in career education, investment in teacher training, reform of teaching contents and methods and perfectness of career educational system.

(3) Control variables. The complexity of teachers is measured by designing the problems in 3 aspects, i.e. subject background, professional qualification background and original post.

Sample and Features. This study took pubic universities, private universities, independent colleges, vocational and academic colleges in Hubei Province as the sample. Questionnaires were distributed through two channels: 1 . The questionnaires in written form were distributed to attending representatives at the career planning annual conference 2012; 2. The questionnaires in electronic form were sent to career planning teachers in all kinds of universities and colleges in Hubei Province through the internet. Among 150 questionnaires distributed, 103 copies were received at a percentage of about $68 \%$. After removing 37 copies not completely filled or filled by teachers outside Hubei Province, 66 copies completed by teachers inside Hubei Province were valid. Among the interviewed teachers, $89 \%$ were under age 40 ; 68\% were from public universities, and 32\% from private universities, independent colleges, vocational and academic colleges; $82 \%$ started teaching the course of career education after 2007; and 74\% had the degree of master or higher level. With regard to subject background, these teachers were evenly allocated in such subjects as "management, education, psychology, science and engineering, humanities and social sciences". Among them, 47\% were at the post of counselor, and others were holding different posts. As shown in the frequency distribution of the attached table, the authenticity and reliability of the questionnaire survey is guaranteed to a high degree.

\section{Empirical Analysis}

Validity and Reliability Analysis. The questionnaire used in this study was independently designed by the author based on the results of interview with career education teachers. After designing the questionnaire, career education teachers of the university were asked to complete the questionnaire, and then some questions and contents were modified on this basis. Hence, the questionnaire has very good validity of contents. The Cronbach's Alpha values of dependent variables and independent variables in this questionnaire are both higher than 0.7 (see Table 4-1 and Table 4-2), indicating good validity of these variables. In addition, the construct validity of the model is shown in Table 4-1. All measured items have the factor load higher than 0.6 in related construct. The cumulative explanation of dependent variables is higher than $55 \%$, while the cumulative variance explanation of independent variables is higher than $70 \%$, so the scale has very good convergent validity.

Table 4-1 Results of factor analysis and reliability analysis for dependent variables

\begin{tabular}{|c|c|c|c|c|}
\hline Variable & Measurement Description & $\begin{array}{l}\text { Factor } \\
\text { Load }\end{array}$ & $\begin{array}{c}\text { Variance } \\
\text { Explanation }\end{array}$ & $\begin{array}{l}\text { Cronbach's } \\
\text { Alpha }\end{array}$ \\
\hline \multirow{5}{*}{$\begin{array}{l}\text { Teacher } \\
\text { satisfaction }\end{array}$} & $\begin{array}{l}\text { Satisfaction with the annual financial investment in } \\
\text { career planning education }\end{array}$ & 669 & \multirow{5}{*}{$55.6 \%$} & \multirow{5}{*}{.795} \\
\hline & $\begin{array}{l}\text { Satisfaction with the spread of career planning } \\
\text { education and its ideas in universities }\end{array}$ & .768 & & \\
\hline & $\begin{array}{l}\text { Satisfaction with the investment in career planning } \\
\text { teaching and practical system for college students }\end{array}$ & .831 & & \\
\hline & $\begin{array}{l}\text { Satisfaction with the teaching and practical system of } \\
\text { career planning educational system for college students }\end{array}$ & .818 & & \\
\hline & $\begin{array}{llll}\begin{array}{l}\text { Satisfaction with students' cognition of career } \\
\text { development }\end{array} & & & \\
\end{array}$ & .619 & & \\
\hline
\end{tabular}

KMO value: .809, Bartlett’s Test of Sphericity is 93.968, which is significant at 0.001 . 
Table 4-2 Results of factor analysis and reliability analysis for independent variables

\begin{tabular}{|c|c|c|c|c|}
\hline Variable & Measurement Description & $\begin{array}{l}\text { Factor } \\
\text { Load }\end{array}$ & $\begin{array}{c}\text { Variance } \\
\text { Explanation }\end{array}$ & $\begin{array}{l}\text { Cronbach's } \\
\text { Alpha }\end{array}$ \\
\hline \multirow{2}{*}{$\begin{array}{l}\text { Financial } \\
\text { investment }\end{array}$} & $\begin{array}{l}\text { In what way financial investment is made in the tailored career } \\
\text { planning and counseling for students }\end{array}$ & .727 & \multirow[b]{2}{*}{28.039} & \multirow[b]{2}{*}{.741 } \\
\hline & $\begin{array}{l}\text { Stability of source of fund for the practical activities in the } \\
\text { career planning for college students }\end{array}$ & .717 & & \\
\hline \multirow{2}{*}{$\begin{array}{l}\text { Investment } \\
\text { in training }\end{array}$} & $\begin{array}{l}\text { Number of teachers organized to attend career planning } \\
\text { training every year }\end{array}$ & 600 & \multirow{2}{*}{16.311} & \multirow{2}{*}{.744} \\
\hline & $\begin{array}{l}\text { Total time you spend in related trainings and academic } \\
\text { seminars }\end{array}$ & .790 & & \\
\hline \multirow{2}{*}{$\begin{array}{l}\text { Contents } \\
\text { and } \\
\text { methods }\end{array}$} & $\begin{array}{l}\text { Main forms of career planning counseling provided for } \\
\text { students }\end{array}$ & .834 & \multirow{2}{*}{15.347} & \multirow{2}{*}{.719} \\
\hline & $\begin{array}{l}\text { Specific channels employed by universities to promote the } \\
\text { concept of career planning }\end{array}$ & .776 & & \\
\hline \multirow{2}{*}{$\begin{array}{l}\text { Career } \\
\text { educational } \\
\text { system }\end{array}$} & Deficiencies in establishment of career planning system & .820 & \multirow[b]{2}{*}{11.413} & \multirow[b]{2}{*}{.762} \\
\hline & $\begin{array}{l}\text { Main forms of guidance to eliminate the confusions in career } \\
\text { planning }\end{array}$ & .770 & & \\
\hline
\end{tabular}

KMO value: .577, Bartlett's Test of Sphericity is 68.884 , which is significant at 0.001 , and the cumulative variance explanation is $71.110 \%$.

Regression Estimation and Hypothesis Testing. In this study, the relevant data are gathered through questionnaire survey and put into regression analysis with spss19.0 software. The results of regression analysis are presented in Table 4-3. As revealed in Table 4-3, the financial investment, investment in training and establishment of career educational system of universities have significant positive influence on the satisfaction of career planning education, so the research hypotheses $\mathrm{H} 1$, $\mathrm{H} 2$ and $\mathrm{H} 4$ are true. The regression coefficient of contents and methods of career education to teacher satisfaction is negative, so it does not match with the theoretical hypothesis, and it is insignificant at 0.05 . Hence, the hypothesis $\mathrm{H3}$ is not true. Clearly, the existing sample in this study cannot prove the influence of the sufficient contents and methods of career education on teacher satisfaction.

Table 4-3 Regression of independent variables

\begin{tabular}{l|l|l}
\hline & \multicolumn{1}{|c}{$\begin{array}{c}\text { Teacher Satisfaction and } \\
\text { Regression of Independent } \\
\text { Variables }\end{array}$} & \multicolumn{1}{c}{ Testing Result } \\
\hline Financial investment & $.566^{* *}(5.936)$ & H1 is true \\
\hline Investment in teacher training & $.241^{* *}(2.434)$ & H2 is true \\
\hline $\begin{array}{l}\text { Reform of contents and } \\
\text { methods }\end{array}$ & -.183 & H3 is not verified \\
\hline Career educational system & $.232^{*}(2.468)$ & H4 is true \\
\hline $\mathrm{R}^{2}$ & .510 & \\
\hline Adjusted $\mathrm{R}^{2}$ & .477 & \\
\hline Sample size & 66 & \\
\hline
\end{tabular}

The $t$ value is bracketed, and the significance level is ** $\mathrm{p}<0.01, * \mathrm{p}<0.05$

\section{Conclusion and Discussions}

This paper aims to explore the factors influencing the satisfaction of career planning teachers with the teaching and research environment of career education for college students, and explain the differences between the satisfaction of career education teachers from different universities with their career education. Based on the research achievements of the predecessors, this paper constructs a theoretical model and performs the empirical study on 66 teachers from universities and colleges in Hubei. As revealed in the study, universities' financial investment in career 
education, investment in teacher training, and management of career educational system have significant positive influence on the satisfaction of career planning teachers. However, this study does not verify the influence that universities' support to the reform and exploration of teachers in teaching contents and methods has on the satisfaction of career planning teachers with career education for college students. Moreover, the complexity of teachers' qualifications and their original posts has significant influence on these variables.

(1) The investment of universities in career education has significant positive influence on the satisfaction of career planning teachers. The investment mainly includes financial investment and investment in training. Career education started very late in China. However, it takes a long time to train the teachers for career education. For this reason, universities must keep investing in career education, and urge teachers to obtain the professional qualifications, so as to improve their professional capabilities for career education. In this way, universities can lay a foundation for expanding the scope of career education service, so as to improve the confidence and satisfaction of teachers.

(2) The perfectness of career educational system in universities has significant positive influence on the satisfaction of career planning teachers with the teaching and research environment. Career education is not a course or a competition, but an educational system with a series of contents including course, practice, internship and counseling, which last for the whole college education and even for a while after finding a job. Hence, universities should properly design the career educational system, especially top down design, and construct an education and counseling service system in five aspects, i.e. teaching system, practical system, counseling system, assessment system and guarantee system, so as to effectively facilitate the career planning and development of college students. Career education is blended with professional education, and professional teachers are also included into the team of career education teachers, so as to improve the satisfaction of teachers for career education.

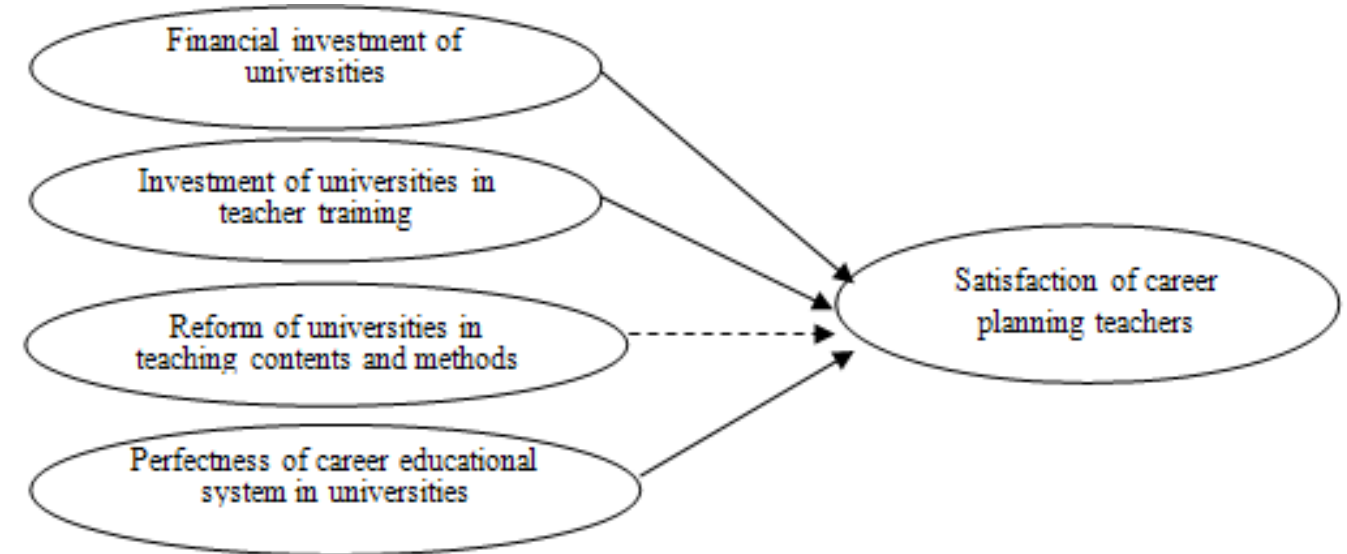

Fig. 2 Verified influence of educational environment on satisfaction of career planning teachers Note: The solid lines in this figure represent positive influence, and the dotted line represents the unverified positive influence.

\section{Acknowledgments}

This article is the 12th Five-years Plan of National Science of Education, the Key Research Project of the Ministry of Education funding. (Project No. 2014317) 


\section{References}

[1] N.G. Lu, Y.N. Zhong, An overview of teacher professional development in an international perspective, Comparative Education Review, 189 (2006), 71-76.

[2] Z.P. Liu, Research on the mechanisms for cultivating university students' career planning awareness, Suzhou University, Suzhou, (2007).

[3] B.K. Li, Q.H. Liu, An discussion about establishment of career planning system for college students, China Higher Education Research, 1 (2005), 76-77.

[4] M. Xu, X.P. Chen, Establishment of curricular system for career planning in the action-oriented and project-based manner, Higher Education Forum, 4 (2011), 98-101.

[5] J.X. Huang, L.X. Zhu, M. Zhao, Analysis on current status of career education for college students. School Party Building and Ideological Education, 32 (2011), 80-81. 